\title{
REGULATION AND ENFORCEMENT OF COMPETITION POLICY
}

\author{
Liviana Andreea Niminet \\ Vasile Alecsandri University of Bacau \\ liviananiminet@yahoo.com
}

\begin{abstract}
Competition policy starts by shaping a legislative framework. This is aimed to establish boundaries for conducting competition and also sets limits of licit and illicit demarcation, for competitive and anticompetitive practices. The Romanian Competition Law has a divalent approach and it aims to provide specific behavioral conditions in order to stimulate and protect free-market competition, with the ultimate goal of developing a balanced, efficient and competitive economy. Our country's Competition policy is based on punishing the behavior. There are three such types of anti-competitive behavior, namely: agreements between undertakings, abuse of dominant position and mergers and other concentrations between undertakings. Recent Practice proved that this "enforcement-conduct-punishment" structure is not necessary the best way to address competition and it is high time for authorities to switch both regulation and enforcement of competition from the "classical perspective" towards concepts like "competition advocacy" and "soft power" and give competition policy a new, reshaped face.
\end{abstract}

\section{Keywords}

competition policy; regulation; enforcement; competitive; anticompetitive practices

\section{JEL Classification}

K20; L40

\section{Introduction}

A highly spread definition for Competition policy is the use of theoretical paradigms by entities with supervisory role of the economy based on the principles and methods of strategic and considering the effects obtained with the aim to promote and maintain effective competition for efficient resource allocation (Moşteanu T., 2010).

The first step in implementing competition policy is shaping a legislative framework to establish boundaries for conducting competition that sets limits of licit and illicit demarcation, the concurrency and anticompetitive. Regulating competition in Romania was established by Law 21/1996 (entered into force on 1 February 1997).

The above mentioned law has a twofold approach: on the one hand, from businesses perspective it aims to realize the significance of competition freedom, on the other hand it aims to establish a state policy promoted by special authorities designated with the role of finding the natural way to fulfill conditions of competition. The main objectives of the Competition Act is to provide specific behavioral conditions to stimulate and protect free-market competition, with the ultimate goal of developing a balanced, efficient and competitive (Moşteau T., 2004) economy not only at state level but also on the global one. All these objectives are to ensure social welfare and to create consumers protection.

In terms of law addressability it has in view, as stated in art. 2 paragraph 1 , the undertakings or associations of undertakings (natural persons or legal entities) by Romanian or foreign nationality who by their deeds or acts causing effects of 
restricted commercial free-market competition and central government and local organisms that by the measures they take influence market operations, having effects on competition except when these measures serve other law enforcement or protection of a capital interest.

\section{Competition policy enforcement in Romania}

Competition policy in our country is based on punishing the behavior. There are three such types of anti-competitive behavior, namely: agreements between undertakings, abuse of dominant position and mergers and other concentrations between undertakings.

\subsection{Agreements between undertakings}

Are prohibited all agreements between undertakings, decisions by associations of undertakings and concerted practices which have as their object or result in prevention, restriction or distortion of competition on the market in Romania or, where applicable, a part of this market. The law specifically refers to the following:

- The establishment directly or indirectly of selling prices inclusive of other trading conditions investment;

- Limiting or controlling production or markets, technical development or

- Share of markets or sources supply

- applying dissimilar conditions to equivalent transactions in relations with trading partners, thus causing some of them a competitive disadvantage;

-contracts subject to acceptance by the other parties of a supplementary clause, by their nature or according to commercial wears, not related to the subject of the contracts

-concerted participation with rigged bids in auctions or other forms of competitive tendering

- eliminating other entrants, limiting or preventing access to the market or free competition from other companies and agreements not to buy from or sell to certain undertakings without reasonable motivation.

Are exempted by law from applying those understandings and categories of agreements, decisions or category of decisions by associations of undertakings, concerted practices or categories of concerted practices that meet the following three conditions:

- contribute to the production or distribution of goods or to promoting technical progress or, where appropriate, economic, while allowing consumers a fair share of the resulting benefit participants in understanding, decision or concerted practice

- does not restrict indispensable for achieving these business

objectives

- offers no possibility of eliminating competition on a substantial part of the concerned market.

EU involvement is to establish regulations by the European Council or the European Commission to ensure the proper application of Article 101 paragraph 3 of the Treaty on the Functioning of the EU, regulations set exceptions for categories of agreements, decisions by associations of undertakings or concerted practices. These types of exceptions are known as Block Exemption Regulations / block

Whenever agreements or concerted practices or decisions, as appropriate, or fall into the categories listed or meet the three cumulative conditions set out above, they are considered legal without any notification made by the parties or the issuance of a 
decision by Competition Council. To the extent that agreements, decisions or concerted practices affecting trade between Member States, the Council of Competition Law applies not only Romanian, but on the Functioning of the European Union, given article 101 of the treaty. The burden of proof in all cases rests on Competition Council.

Practice reveals a variety of anticompetitive practices that firms use to obtain competitive advantages. Legal agreements between undertakings are divided into two categories namely:

a) Understanding legal structures, namely those agreements express or tacit agreements between undertakings

b) Understanding legal unstructured includes concerted practices of economic agents to adapt to the conduct of competitive environment

a) Form of guilt in committing these practices is the intention, and in this form they are covered by the law. There are certain practices that admit guilt as a form of guilt that is limiting production, markets, technical development or investment. The essential condition for the practice to be banned is that it significantly affects the competitive environment.

Agreements between companies can target supply of raw materials, production conditions, business or any other element of the market. These arrangements should aim to eliminate competition between participants by restricting production, rising prices, sales area sharing. If you were to look at things through the prism of firms, it is clear that the motivation of such practices could increase business efficiency through economies of scale through standardization of products, reducing the risks of creating new products or entering new markets. Yet this practice is neither a moral, ethical or legal alone.

Arrangements can take two forms namely express when found by writing or silent when there is no written record.

Concerted practice is defined as the manifestation of economic competitors in the relevant market, adopts a similar behavior with the effect of restricting, preventing or distorting competition in the absence of collusion between them. In practice, an express agreement between operators in an industry may take the form of a cartel aimed at maximizing profits by controlling the output of each firm and the selling price. After their purpose or market sharing cartels may target the imposition prices.

An example of economic concentration is Decision 148/2006 of the Competition Council. In fact CROSS LANDER USA Inc. Company has gained control over SC ARO SA Campulung under contract for the sale of shares. Council Decision was that according to the law, namely Article 11 paragraph 2, letter b) of Law 21/1996 on competition in the acquisition of sole control over SC ARO SA Campulung by CROSS LANDER USA Inc. ${ }^{1}$ is an economic concentration.

An economic classification of agreements distinguishes between:

- Horizontal agreements which concern economic operators at the same level of economic processes (e.g. agreements between producers, agreements between distributors)

- Vertical agreements concerning operators at different levels of the same economic process (e.g. agreements between manufacturers and distributors of the same product).

Horizontal Agreements usually have a greater affect on the competitive environment while vertical agreements in certain circumstances may have beneficial

\footnotetext{
${ }^{1}$ CROSS LANDER USA Inc. Changed its name to GLOBAL VEHICLES USA Inc., as it results from the name changing certificate issued by the State Secretary of Nevada USA, certificate anexed to the Letter of response of the Competition Council No. DIE/1083/21.06.2006.
} 
effects for competition such as economic efficiency, or effects on consumers and, therefore, fall within the categories exempted from the Competition Act as shown above.

In this subject analysis, agreements between car manufacturers can take the following forms:

- Agreements for the purchase of licenses for different models, services, vertical relationships with suppliers and distributors, exchange of parts and mechanical parts, in terms of disposal and recycling and last but not least, the agreements relate to financing activities automotive supplies;

- Joint projects correspond to a commitment that two manufacturers undertake mutually to share responsibilities and funding research and development into productive investments directly involved. There are such consortia in Japan, USA (USCAR) and the European Union (EUCAR). Also to be noted the agreement between PSA and Ford on developing a new diesel engine generation, Renault and G.M.

- Co enterprises (joint venture) in joint projects, respecting autonomy of builders: association with local partners or other manufacturers. Note here the association with Renault Toyota in SOFASA after 1990 for Columbia. In the 80's Japanese implantation started in North America with associations: General Motors for Toyota (NUMMI) and Suzuki (CAMI) Chrysler for Mitsubishi (DiamondStar) and Ford for Mazda (Auto Alliance)

- Financial holdings in the capital of builders: e.g. pre-crisis situation at the time when Ford owned 33.3\% of Mazda, GM owned 20\% of the capital of Suzuki, Daimler Chrysler had Mitsubishi under control by 37\%, Nissan 15\% of Renault's capital, although the latter holds $44 \%$ of Japanese manufacturer capital, and so on;

- $\quad$ Mergers and acquisitions partnerships between manufacturers and insurers. They are a special case because trademark policy refers to the positioning of car manufacturers ensured regarding the quality of post acquisition.

\subsection{Dominant position abuse}

Abuse of dominant position is a serious anti-competitive practice with a variety of forms ranging from the imposition of price, the use of predatory pricing or discriminatory setting unequal conditions to equivalent transactions made by those who hold a large economic power on market and aim to eliminate direct competitors.

At European level ECJ has defined dominance as "position of economic strength enjoyed by an undertaking which enables it to hinder the maintenance of effective competition on the relevant market, thus giving power to behave independently of its competitors, its clients and in the end-to-consumer ".

Obtaining an important position in a market is a very important strategic objective for many competitors, an objective that can be achieved by adopting appropriate marketing strategies. Once gained this position through consistent and appropriate marketing tactics, it can become a position of market dominance.

One should clearly understand that dominant position of a trader in a market, is not unlawful in itself. Law only penalizes abuse of dominance. But it is easy to assume that holding a dominant position the firm is tempted to speculate that by adopting a specific competitive behavior. If, however, other competitors will be able to counteract its actions through thoughtful marketing action than there will be no dominant position held by the entity in question. It is considered that a firm is dominant if, on the relevant market, it can act largely independently (Mereuţă C., 2004). 
In order to determine the position on the market first market segments should be measured. ECJ case law considers that a market share of $75 \%$ maintained for a long period of time proves the existence of a dominant position. If market share is between 40 and $75 \%$ then to establish abuse of dominance other elements are needed. In Romania the law prohibits the abuse of a dominant position by one or more undertakings on the Romanian market or in a substantial part of the market.

Are considered abusive one of the following actions:

- Direct or indirect imposition of certain unfair prices for sale or purchase or other unfair trading conditions and refusing to deal with suppliers or beneficiaries

- limiting production, markets or development to the prejudice of consumers;

- applying dissimilar conditions to equivalent transactions between business partners, thus causing some of them a competitive disadvantage

- The conclusion of contracts subject to acceptance by the other parties of supplementary obligations which by their nature or according to usage trade have no connection with the subject of such contracts;

-Practicing over pricing or practicing predatory pricing to eliminate competitors or export sale below cost, to bridge the gap by imposing higher prices to domestic consumers

- exploitation of the dependence of another enterprise to an such organization or enterprise that does not have an alternative in conditions equivalent and ground breaking contractual relations partner refusal to submit to unjustified commercial conditions.

An analysis of anticompetitive practices shown on the abuse of a dominant position can only be done very carefully and considering each case.

Let us take the example of price competition that has long been a strategy of major companies in an attempt to gain a significant share of the market. Businesses engaged in a "price war" over a period of time, which have the effect of eliminating competitors. In some situations, a price below cost can be a strategic option when you want to enter a new market, attracting a segment of consumers, eliminating stock products, conducting promotional campaigns etc. Price predation is usually practiced by a dominant undertaking in the relevant market, which aims to eliminate a competitor and involves either selective price reductions or impose a price that is not profitable.

Conditional sales are another situation worthy of attention since they involve selling a product subject to the purchase of another product that could be purchased on terms more favorable from another supplier or when a service provider is subject to the purchase of a product or the provision of other service. As in the case of agreements between undertakings and abuse of dominant position which affects trade between Member States Competition Council applies the EU Treaty provisions, namely art. 102. Until proven otherwise works the assumption that if the cumulative share or shares in the relevant market in the period, not exceed $40 \%$ we cannot speak of a dominant position that can be abused.

\subsection{Economic concentrations}

In the law understanding is considered to be concentration the lasting change of control resulting from:

1) Merger of two or more undertakings which were previously independent undertakings or parts thereof,

2) Acquisition by one or more persons already controlling at least one undertaking, or by one or more undertakings, whether by purchase of securities or assets, by contract or by any other means, direct or indirect control over one or several undertakings or parts thereof. 
3) Concentration is also creating an entirely sustainable company which functions as an autonomous economic entity.

Summarizing, we can say that the concept of merger shall circumscribed three categories

- Mergers,

- Acquisitions by acquiring control,

- Concentrative joint venture creation.

Let us have a look at each of these types of mergers. Mergers can take many forms:

- Fusion by merger when two or more companies merge into a new undertaking. Following is terminated two original businesses and generates a new agent

- Merger by absorption in the situation when a trader is embedded by another undertaking. The last of them, the one that encompasses retain legal personality, while the first, the embedded ceases to exist as a legal entity;

- de facto merger when two or more independent economic agents, yet maintaining legal personality, combine their operations creating a competitive group that is manifested as a single economic entity, in the absence of a legal act.

The purpose behind creating a merger may be different going from a desire to increase economic efficiency, increase market power, the desire for diversification, expansion of geographical markets and to avoid for reasons of insolvency.

OECD classified mergers as it follows:

- Horizontal merger refers to the association between competitors (which produce and sell the same products in the relevant market). If they are representative of size, horizontal mergers may reduce competition in the market, often under the supervision of competition. authorities

- Vertical mergers occur between economic agents operating in various stages of production, from raw materials to finished products in the distribution phase, their effect is reflected usually in economic efficiency, although some may have anti-competitive impact

- Conglomerate mergers which take the form of an association of undertakings in unrelated sectors.

Through a merger may enhance market power or create market power as it can facilitate its exercise, to the extent that it significantly increases the degree of market concentration and if it leads to a concentrated market, defined and measured correctly. Mergers, which don't significantly increase the degree of market concentration or do not lead to this result usually, do not require further analysis of relevant institutions

It is also required a mention about the latest form of economic concentration achieved namely by creating a sustainable company which functions as an autonomous economic entity entirely. When the creation of a joint venture by the merger described in 1) has as its object or effect the coordination of the competitive behavior of undertakings that remain independent, they are analyzed on the compatibility with a normal competitive environment according to art 101 of the Treaty on the Functioning of the Union. This analysis follows a series of criteria. The first refers to the situation where two or more companies retain, to a large extent activities in the same market as the joint venture or in a market upstream or downstream from that of the joint venture or a neighboring market closely related to this market. Another criterion relates to verify whether the coordination which is the direct consequence of the creation of joint undertakings concerned the possibility of eliminating competition in a substantial part of the goods or services concerned. 


\section{Conclusions}

The first step in implementing competition policy is shaping a legislative framework that establishes boundaries for competition, for "within law" and "above law" actions. Regulating competition in Romania has a twofold approach: on the one hand, from businesses perspective it aims to realize the significance of competition freedom, on the other hand it aims to establish a state policy promoted by special authorities designated with the role of finding the natural way to fulfill conditions of competition. The main objectives of the Competition Act is to provide specific behavioral conditions to stimulate and protect free-market competition, with the ultimate goal of developing a balanced, efficient and competitive economy both at state level and on the global one. Primary beneficiary is social welfare that ultimately ensures consumers protection.

Competition policy in our country is based on punishing the behavior. There are three such types of anti-competitive behavior, namely: agreements between undertakings, abuse of dominant position and mergers and other concentrations between undertakings. Recent Practice proved that this "conduct-punishment” structure is not necessary the best way to address competition and it is high time for authorities to deal more with concepts like "competition advocacy" and "soft power" when it comes about competition policy.

\section{References}

Glossary of Industrial Economics, Competition Law and Policy (2010), published under the auspices of the General Secretariat of the Organization for Economic Cooperation and Development.

Mereuţă, C. (2004), Abuzul de poziţie dominantă în legislaţia română, Profil: Concurenţa, no.2.

Moşteanu, T. (2000), Concurenţa. Abordări teoretice şi practice, Bucureşti, Editura Economică.

Motta, M. (2004), Competition policy: theory and practice, Cambridge Publishing House.

Nimineţ, L.A. (2009), European competition in time of crisis. To be or not to be, Studies and Scientific Researches, EconomicEdition, Issue 14, p.67-71.

Niminet, L.A. (2012), Turmoil on the Automotive Market: Insight Perspective, BRAND, vol.3, No.3, p.81-84.

Nimineţ, L.A. (2014), Changing the Economic Parameters of Competition Environment, Lambert Academic Publishing (LAP). 